IRA-International Journal of Management \& Social Sciences

ISSN 2455-2267; Vol.07, Issue 03 (2017)

Pg. no. 489-501

Institute of Research Advances

http://research-advances.org/index.php/RAJMSS

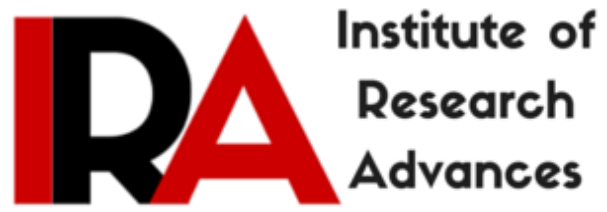

\title{
Union Wise Competitiveness of Kerala Co- Operative Milk Marketing Federation Ltd, Kerala (Milma)
}

\section{Dr. P. P. Lakshmanan}

Associate Professor in Commerce (Retired)

Pazhassi Raja N.S.S. College Mattanur, Kerala, India.

Type of Review: Peer Reviewed.

DOI: http://dx.doi.org/10.21013/jmss.v7.n3.p10

\section{How to cite this paper:}

Lakshmanan, P. (2017). Union Wise Competitiveness of Kerala Co-Operative Milk Marketing Federation Ltd, Kerala (Milma). IRA-International Journal of Management \& Social Sciences (ISSN 2455-2267), 7(3), 489-501. doi:http://dx.doi.org/10.21013/jmss.v7.n3.p10

(C) Institute of Research Advances

\section{(c)) EY-NC}

This work is licensed under a Creative Commons Attribution-Non Commercial 4.0 International License subject to proper citation to the publication source of the work.

Disclaimer: The scholarly papers as reviewed and published by the Institute of Research Advances (IRA) are the views and opinions of their respective authors and are not the views or opinions of the IRA. The IRA disclaims of any harm or loss caused due to the published content to any party. 


\begin{abstract}
Milma, the brand name of Kerala Co-operative Milk Marketing Federation (KCMMF) is carrying out its operations in Kerala with its mission of 'farmer's prosperity through consumer satisfaction'. It could achieve remarkable progress in milk procurement and selling with the implementation of the operation flood programmes. Today it is a matter of pride that 'Milma' is a household name in Kerala. The punch line of Milma is "The goodness Kerala wakes up to." Milma is one of the best brands from the state and is known for its regularity of supply and quality of milk. KCMMF has three unions viz. Trivandrum Regional Co-operative Milk Producers Union (TRCMPU), Ernakulam Regional Co-operative Milk Producers Union (ERCMPU), Malabar Regional Co-operative Milk Producers Union (MRCMPU).This study makes an attempt to analyze the Union wise competitiveness of KCMMF Ltd (Milma).
\end{abstract}

Keywords: Market Growth Rate, Market share, Two by Two Matrix.

\title{
I. Introduction
}

The Kerala Co-operative Milk Marketing Federation Ltd (KCMMF) under the trade name MILMA is the apex body of the dairy co-operatives in Kerala. It is organized like Anand pattern, which has a three tier structure consisting of the primary dairy co-operative societies at village level (Anand pattern co-operative societies or APCOS), three regional Unions and the state level Federation. The Federation at the top is the apex body which controls and co-ordinates the activities of both the regional Unions and the APCOS. Thiruvananthapuram Regional Co-operative Milk Producers Union (TRCMPU) was formed in 1985 and Ernakulam Regional Co-operative Milk Producers Union (ERCMPU) was formed in 1986 followed by Malabar Regional Co-operative Milk Producers Union (MRCMPU) in 1989. The revenue districts of Thiruvananthapuram, Kollam, Alappuzha and Pathanamthitta come under the jurisdiction of TRCMPU, the districts of Ernakulam, Thrissur, Kottayam and Idukki under ERCMPU and the six northern districts of Palakkad, Kannur, Malappuram, Kozhikkode, Wayanad and Kasaragod under MRCMPU. These three Unions perform the operations of KCMMF in their respective regions. They run dairy plants, milk chilling plants, milk procurement and input offices.

During the period 2014-15, KCMMF represents 3206 registered APCOS, of which 2859 functional APCOS comprising 7.33 lakh dairy farmer members. The three regional unions TRCMPU, ERCMPU, and MRCMPU procured an average quantity of 9.96 lakh litres of milk per day Average selling of milk per day by the three unions during the period 2014-15 was 12.29 lakh litres. Turnover of KCMMF during this period was Rs.336.52 crore and its profit after tax during this period was Rs. 0.8 crore. ${ }^{i}$ One of the major inputs provided to the dairy farmer of the state by KCMMF is balanced cattle feed that has high level of acceptability. KCMMF, operates two cattle feed plants-one at Pattanakkad with a capacity of 300 MT per day which produces mash feed and the other at Malampuzha with a capacity of 300 MT per day which produces cattle feed in mash form. Besides the supply of balanced cattle feed, the members of APCOS are provided with veterinary health cover. ${ }^{\text {ii }}$ The Central Product Dairy (CPD) is managed directly by the KCMMF. At present, it has a milk processing plant, an aseptic packaging station and a milk powder plant ${ }^{1}$.

\section{II .Objectives and Methodology}

The study aims to ascertain the current level of competitiveness of various Unions of KCMMF. It is a case study as the study is being confined only to KCMMF. Only secondary data have been used for this study. Secondary data were collected from the annual reports of KCMMF. The study was conducted for the period of five years from 2010-11 to 2014-15. Mathematical tools like percentage and average were used for the analysis and interpretation of data. Moreover Two by two matrix was also used to 
analyze the data. It represents four cells. On vertical axis average growth rate and on horizontal axis average market share of selling of milk and milk products of unions were taken. Mid value of average growth rate was calculated by dividing the total of three union's average growth rate by three. Similarly mid value of average market share was calculated by dividing the total of three unions average market share by three. Cell I represents high market share and high growth rate, Cell II represents high market share and low growth rate, Cell III represents high growth rate and low market share and Cell IV represents low market share and low growth rate. Cell I denotes very high position, Cell II denotes high position, Cell III denotes moderate position and Cell IV denotes low position.

Two by Two Matrix

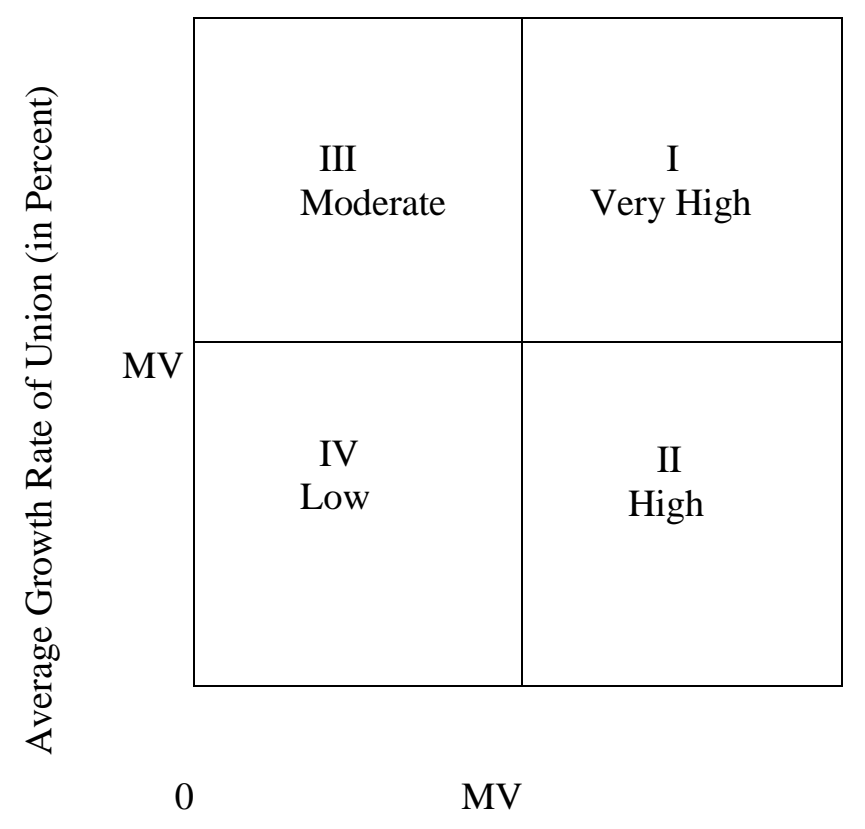

Average Market Share of Union

\section{Data Analysis and Results}

In order to ascertain the current level of competitiveness of various Unions of KCMMF, factors such as union wise procurement of milk, relation between procurement and selling of milk, and union wise selling of milk and milk products such as ghee, butter milk, curd, sambaram, Ice-cream were considered.

\section{III (A) Union wise Procurement of Milk (In Quantity)}

The procurement of milk from various APCOS after meeting the local demand is one of the important functions of dairies. The progress achieved by TRCMPU, ERCMPU and MRCMPU in this respect is shown in Table1. The average annual growth rates of procurement of milk of three unions during the period 2010-11 to 2014-15 shows a steady increase. The average annual growth rate of milk procurement per day of TRCMPU, ERCMPU and MRCMPU during the period 2010-11 to 2014-15 shows 13.1 percent, 10.6 percent and 9.2 percent respectively. TRCMPU showed a highest growth rate in milk 
procurement than other unions. The overall average annual growth rate of milk procurement per day of three unions is 10.4 percent.

Table 1: Annual Growth Rate of Milk Procurement Per Day

\begin{tabular}{|c|c|c|c|c|c|c|c|c|}
\hline & \multicolumn{2}{|c|}{ TRCMPU } & \multicolumn{2}{c|}{ ERCMPU } & \multicolumn{2}{c|}{ MRCMPU } & \multicolumn{2}{c|}{ Total } \\
\hline & $\begin{array}{c}\text { (in Lakh } \\
\text { litres }\end{array}$ & $\%$ & $\begin{array}{c}\text { (in } \\
\text { Lakh } \\
\text { litres }\end{array}$ & $\%$ & $\begin{array}{c}\text { (in Lakh } \\
\text { litres }\end{array}$ & $\begin{array}{c}\text { (in Lakh } \\
\text { litres }\end{array}$ & $\%$ \\
\hline $2010-11$ & 1.50 & - & 1.56 & - & 3.66 & - & 6.72 & - \\
\hline $2011-12$ & 1.88 & 25.3 & 1.76 & 12.8 & 4.19 & 14.5 & 7.83 & 16.5 \\
\hline $2012-13$ & 2.07 & 10.1 & 2.06 & 17.0 & 4.67 & 11.5 & 8.80 & 12.4 \\
\hline $2013-14$ & 2.31 & 11.6 & 2.20 & 6.8 & 4.91 & 5.1 & 9.42 & 7.0 \\
\hline $2014-15$ & 2.43 & 5.2 & 2.33 & 5.9 & 5.20 & 5.9 & 9.96 & 5.7 \\
\hline Average & 2.04 & 13.1 & 2.04 & 10.6 & 4.53 & 9.2 & 8.55 & 10.4 \\
\hline
\end{tabular}

Source: Annual Reports of KCMMF

\section{III (B) Union wise Selling of Milk (In Quantity)}

The annual growth rates of milk sales per day by all unions of KCMMF showed a mixed trend. Moreover in certain years it showed a negative growth rate. The average annual growth rate of milk sales per day of TRCMPU, ERCMPU and MRCMPU during the period 2010-11 to 2014-15 showed 2.1 percent, 3.1 percent and 3.5 percent respectively. MRCMPU showed a highest growth rate in milk sales among three unions. The overall average annual growth rate of milk sales per day of three unions was 2.9 percent (Table 2).

Table 2: Annual Growth Rate of Milk Sales Per Day

\begin{tabular}{|c|c|c|c|c|c|c|c|c|}
\hline & \multicolumn{2}{|c|}{ TRCMPU } & \multicolumn{2}{c|}{ ERCMPU } & \multicolumn{2}{c|}{ MRCMPU } & \multicolumn{2}{c|}{ Total } \\
\hline & $\begin{array}{c}\text { (in Lakh } \\
\text { litres }\end{array}$ & $\%$ & $\begin{array}{c}\text { (in } \\
\text { Lakh } \\
\text { litres }\end{array}$ & $\%$ & $\begin{array}{c}\text { (in Lakh } \\
\text { litres }\end{array}$ & $\begin{array}{c}\text { (in Lakh } \\
\text { litres }\end{array}$ & \\
\hline $2010-11$ & 4.34 & - & 2.73 & - & 3.92 & - & 10.99 & - \\
\hline $2011-12$ & 4.68 & 7.8 & 2.96 & 8.4 & 4.11 & 4.8 & 11.75 & 6.9 \\
\hline $2012-13$ & 4.66 & $(-) 0.4$ & 2.99 & 1.0 & 4.23 & 2.9 & 11.88 & 1.1 \\
\hline $2013-14$ & 4.60 & $(-) 1.3$ & 3.04 & 1.7 & 4.23 & 0.0 & 11.87 & $(-) 0.1$ \\
\hline $2014-15$ & 4.71 & 2.4 & 3.08 & 1.3 & 4.5 & 6.4 & 12.29 & 3.5 \\
\hline Average & 4.60 & 2.1 & 2.96 & 3.1 & 4.20 & 3.5 & 11.76 & 2.9 \\
\hline
\end{tabular}

Source: Annual Reports of KCMMF

\section{a. Relation between Procurement and Selling of Milk}

In the case of all unions, the annual growth rate of procurement of milk was higher than the annual growth rate of selling of milk. It showed that milk procurement was faster than milk sales. On an average, the annual growth rate of procurement of milk of all unions was higher than the growth rate of milk sales. (Table 3). 
Table 3: Annual Growth Rate of Milk Procurement and Milk Sales per Day (Percentage)

\begin{tabular}{|c|c|c|c|c|c|c|}
\hline \multirow{2}{*}{ Year } & \multicolumn{2}{|l|}{ TRCMPU } & \multicolumn{2}{|c|}{ ERCMPU } & \multicolumn{2}{|c|}{ MRCMPU } \\
\cline { 2 - 7 } & Procurement & Sales & Procurement & Sales & Procurement & Sales \\
\hline $2011-12$ & 25.3 & 7.8 & 12.8 & 8.4 & 14.5 & 4.8 \\
\hline $2012-13$ & 10.1 & $(-) 0.4$ & 17.0 & 1.0 & 11.5 & 2.9 \\
\hline $2013-14$ & 11.6 & $(-) 1.3$ & 6.8 & 1.7 & 5.1 & 0.0 \\
\hline $2014-15$ & 5.2 & 2.4 & 5.9 & 1.3 & 5.9 & 6.4 \\
\hline Average & 13.1 & 2.1 & 10.6 & 3.1 & 9.2 & 3.5 \\
\hline
\end{tabular}

Source: Annual Reports of KCMMF

\section{b. Surplus/Deficit of Milk}

As per Table 4, TRCMPU and ERCMPU had deficit of milk in the study periods, whereas MRCMPU had surplus of milk in all the years except 2010-11.Both TRCMPU and ERCMPU showed a decreasing trend in the case of deficit of milk, whereas MRCMPU showed an increasing trend in the case of surplus of milk. On an average TRCMPU showed 2.56 lakh litres of deficit of milk per day, ERCMPU showed 92 thousand litres of deficit of milk per day, and MRCMPU had 33 thousand litres of surplus milk per day. TRCMPU had highest deficit of milk per day.

Table 4: Average Surplus/Deficit of milk per day (Lakh LPD)

\begin{tabular}{|c|c|c|c|}
\hline Year & TRCMPU & ERCMPU & MRCMPU \\
\hline $2010-11$ & (-) 2.84 & (-) 1.17 & (-) 0.26 \\
\hline $2011-12$ & (-) 2.80 & $(-) 1.20$ & 0.08 \\
\hline $2012-13$ & (-) 2.59 & $(-) 0.93$ & 0.44 \\
\hline $2013-14$ & (-) 2.29 & (-) 0.84 & 0.68 \\
\hline $2014-15$ & (-) 2.28 & (-) 0.75 & 0.70 \\
\hline Average & (-) 2.56 & (-) 0.92 & 0.33 \\
\hline
\end{tabular}

Source: Annual Reports of KCMMF

In Figure1, the vertical axis represents the average annual growth rate of milk sales and the horizontal axis represents the average market share of milk sales of three unions. The sign* is given for TRCMPU, '\#' was given for ERCMPU and '\$' was given for MRCMPU. The average growth rate of TRCMPU, ERCMPU MRCMPU was 2.1 percent, 3.1 percent and 3.5 percent respectively. The average market share of TRCMPU, ERCMPU MRCMPU was 4.6 lakh litres per day, 2.96 lakh litres per day and 4.2 lakh litres per day respectively (Table 2). As per Figure 1 MRCMPU had very high position, TRCMPU had high position and ERCMPU had moderate position as regards milk sales. 
Figure 1: Two by Two Matrix of Union wise Milk Sales



Average Market Share of Union

\section{III (C) Union wise Selling of Milk Products}

In order to analyze the current level of competitiveness of unions, union wise selling of milk products such as ghee, butter, curd, sambaram and ice cream was also considered.

\section{a. Union wise Selling of Ghee}

The annual growth rate of selling of ghee by TRCMPU showed a declining trend. But the annual growth rate of selling of ghee by ERCMPU and MRCMPU showed a mixed trend. Moreover the annual growth rate of selling of ghee by MRCMPU in 2012-13 showed a negative trend. The average annual growth rate of selling of ghee by TRCMPU, ERCMPU and MRCMPU was 14.7 percent, 12.7 percent and 6.5 percent respectively.. The overall average annual growth rate of ghee sales of three unions was 9.8 percent (Table 5).

Table 5: Annual Growth Rate of Ghee Sales Per Year

\begin{tabular}{|c|c|c|c|c|c|c|c|c|}
\hline & \multicolumn{2}{|c|}{ TRCMPU } & \multicolumn{2}{l|}{ ERCMPU } & \multicolumn{2}{c|}{ MRCMPU } & \multicolumn{2}{c|}{ Total } \\
\hline & (in MT) & $\%$ & (in MT) & $\%$ & (in MT) & $\%$ & (in MT) & $\%$ \\
\hline $2010-11$ & 815 & - & 615 & - & 1779 & - & 3209 & - \\
\hline $2011-12$ & 994 & 22.0 & 738 & 20.0 & 2068 & 16.2 & 3800 & 18.4 \\
\hline $2012-13$ & 1209 & 21.6 & 769 & 4.2 & 1873 & $(-) 9.4$ & 3851 & 1.3 \\
\hline $2013-14$ & 1302 & 7.7 & 897 & 16.6 & 2097 & 12.0 & 4296 & 11.6 \\
\hline $2014-15$ & 1401 & 7.6 & 988 & 10.1 & 2250 & 7.3 & 4639 & 8.0 \\
\hline Average & 1144 & 14.7 & 801 & 12.7 & 2013 & 6.5 & 3959 & 9.8 \\
\hline
\end{tabular}

Source: Annual Reports of KCMMF 
The average growth rate of TRCMPU, ERCMPU MRCMPU was 14.7 percent, 12.7 percent and 6.5 percent respectively. The average market share of TRCMPU, ERCMPU MRCMPU was 1.1'000 MT per year, 0.8'000 MT per year, and 2.0 1'000 MT per year respectively (Table 5). As per Figure 2 MRCMPU had high position, TRCMPU and ERCMPU had moderate position in respect of ghee sales.

Figure 2: Two by Two Matrix of Union wise Ghee Sales

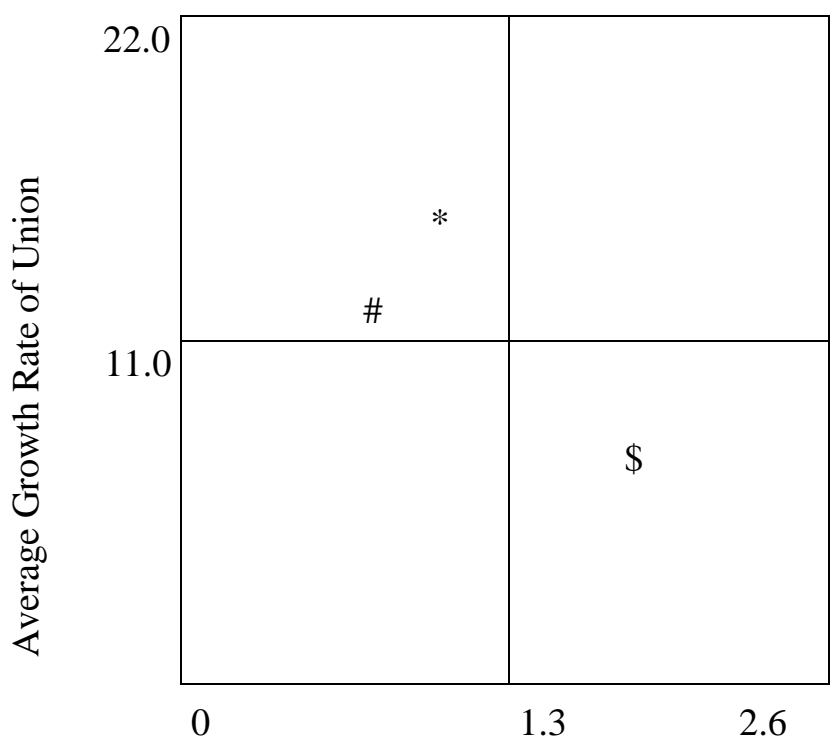

\section{b. Union wise Selling of Butter}

Average Market Share of Union

The annual growth rate of selling of butter by all unions showed mixed trend. MRCMPU started to sell butter in2012-13. The annual growth rate of selling of butter by MRCMPU was very high in 2013-14 and in the next year it showed a decreasing trend. . The average annual growth rate of selling of butter by TRCMPU, ERCMPU and MRCMPU was 26.6 percent, 24.2 percent, and 34.7 percent respectively. The overall average annual growth rate of butter sales of three unions was 36.0 percent (Table 6).

Table 6: Annual Growth Rate of Butter Sales Per Year

\begin{tabular}{|c|c|c|c|c|c|c|c|c|}
\hline & \multicolumn{2}{|c|}{ TRCMPU } & \multicolumn{2}{c|}{ ERCMPU } & \multicolumn{2}{c|}{ MRCMPU } & \multicolumn{2}{c|}{ Total } \\
\hline & (in MT) & $\%$ & (in MT) & $\%$ & (in MT) & $\%$ & (in MT) & $\%$ \\
\hline $2010-11$ & 65 & - & 54 & - & - & - & 119 & - \\
\hline $2011-12$ & 99 & 52.3 & 85 & 57.4 & - & 0.0 & 184 & 54.6 \\
\hline $2012-13$ & 124 & 25.3 & 97 & 14.1 & 7 & 0.0 & 228 & 23.9 \\
\hline $2013-14$ & 159 & 28.2 & 107 & 10.3 & 42 & 500.0 & 308 & 35.1 \\
\hline $2014-15$ & 160 & 0.6 & 123 & 15.0 & 119 & 183.3 & 402 & 30.5 \\
\hline Average & 121 & 26.6 & 93 & 24.2 & 34 & 34.7 & 248 & 36.0 \\
\hline
\end{tabular}

Source: Annual Reports of KCMMF 
The average growth rate of TRCMPU, ERCMPU MRCMPU was 26.6 percent, 24.2 percent and 34.7 percent respectively. The average market share of TRCMPU, ERCMPU MRCMPU was 1.2'00 MT per year, 0.9'00 MT per year, and 2.5 '00 MT per year respectively (Table 6). As per Figure 3, TRCMPU and ERCMPU had high position and MRCMPU had moderate position, as regards butter sales.

Figure 3: Two by Two Matrix of Union wise Butter Sales

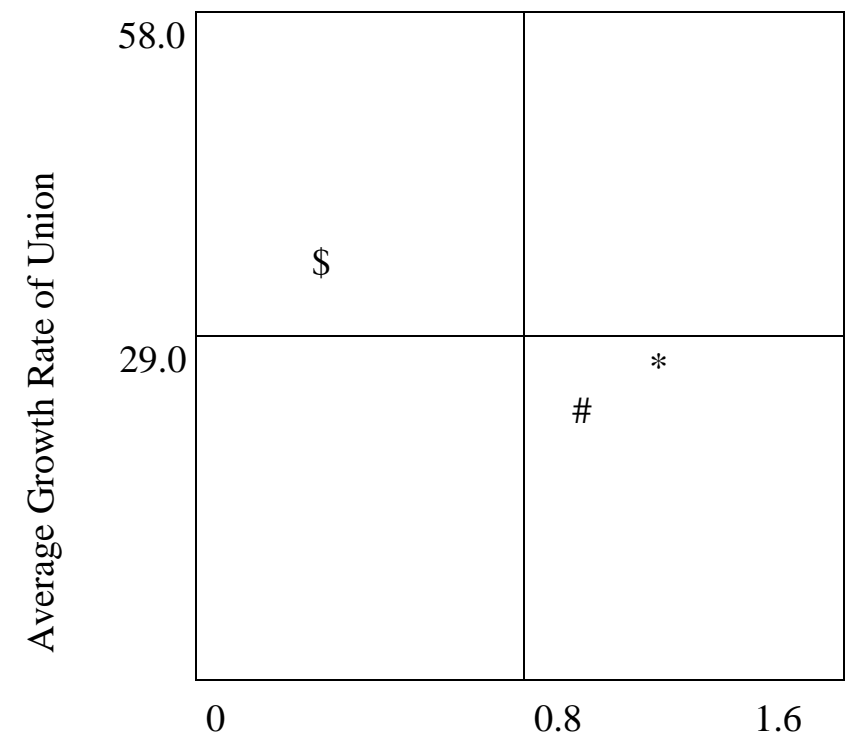

Average Market Share of Union

\section{c. Union wise Selling of Curd}

The annual growth rate of selling of curd by TRCMPU showed mixed trend. But The annual growth rate of selling of curd by ERCMPU and MRCMPU showed a decreasing trend. The annual growth rate of selling of curd by MRCMPU in 2014-15 showed a negative growth rate. The average annual growth rate of selling of curd by TRCMPU, ERCMPU and MRCMPU was 8.9 percent, 5.7 percent, and 5.2 percent respectively. The overall average annual growth rate of curd sales of three unions was 6.0 percent (Table 7).

Table 7: Annual Growth Rate of Curd Sales Per Year

\begin{tabular}{|c|c|c|c|c|c|c|c|c|}
\hline & \multicolumn{2}{|c|}{ TRCMPU } & \multicolumn{2}{c|}{ ERCMPU } & \multicolumn{2}{c|}{ MRCMPU } & \multicolumn{2}{c|}{ Total } \\
\hline & (in MT) & $\%$ & (in MT) & $\%$ & (in MT) & $\%$ & (in MT) & $\%$ \\
\hline $2010-11$ & 4486 & & 4204 & & 15418 & & 24108 & \\
\hline $2011-12$ & 5045 & 12.5 & 4734 & 12.6 & 17089 & 10.8 & 26868 & 11.4 \\
\hline $2012-13$ & 5747 & 13.9 & 5081 & 7.3 & 18424 & 7.8 & 29252 & 8.9 \\
\hline $2013-14$ & 6253 & 8.8 & 5195 & 2.2 & 18911 & 2.6 & 30359 & 3.8 \\
\hline $2014-15$ & 6284 & 0.5 & 5233 & 0.7 & 18787 & $(-) 0.7$ & 30304 & $(-) 0.2$ \\
\hline Average & 5563 & 8.9 & 4889 & 5.7 & 17726 & 5.2 & 28178 & 6.0 \\
\hline
\end{tabular}

Source: Annual Reports of KCMMF 
The average growth rate of TRCMPU, ERCMPU MRCMPU was 8.9 percent, 5.7 percent and 5.2 percent respectively. The average market share of TRCMPU, ERCMPU MRCMPU was 5.6'000 MT per year, 4.9'000 MT per year, and17.7'000 MT per year respectively (Table 7). As per Figure 4, MRCMPU had high position, TRCMPU had moderate position and ERCMPU had low position in respect of curd sales.

Figure 4: Two by Two Matrix of Union wise Curd Sales

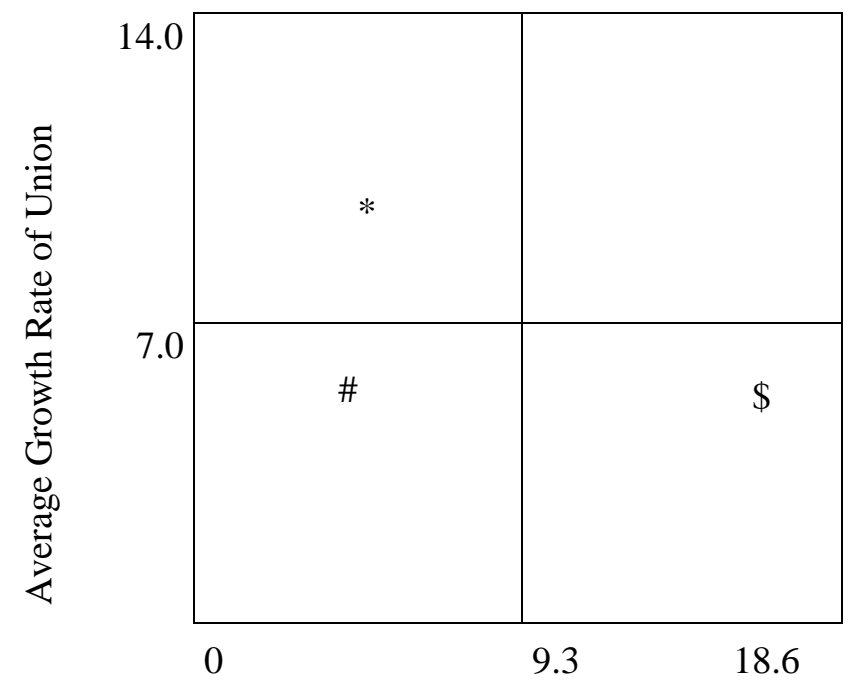

Average Market Share of Union

\section{d. Union wise Selling of Sambaram}

The annual growth rate of selling of sambaram by all unions showed mixed trend. Moreover the annual growth rate of selling of sambaram by TRCMPU and ERCMPU showed a negative growth rate in 2014-15. The average annual growth rate of selling of sambaram by TRCMPU, ERCMPU and MRCMPU was (-) 2.3 percent, 6.7 percent, and 18.3 percent respectively. The overall average annual growth rate of sambaram sales of three unions was 15.5 percent (Table 8).

Table 8: Annual Growth Rate of Sambharam Sales Per Year

\begin{tabular}{|c|c|c|c|c|c|c|c|c|}
\hline & \multicolumn{2}{|c|}{ TRCMPU } & \multicolumn{2}{|c|}{ ERCMPU } & \multicolumn{2}{c|}{ MRCMPU } & \multicolumn{2}{c|}{ Total } \\
\hline & $\begin{array}{c}\text { (in } \\
\text { Lakh } \\
\text { Packets } \\
\text { ) }\end{array}$ & $\%$ & $\begin{array}{c}\text { (in Lakh } \\
\text { Packets) }\end{array}$ & $\%$ & $\begin{array}{c}\text { (in Lakh } \\
\text { Packets) }\end{array}$ & $\%$ & $\begin{array}{c}\text { (in Lakh } \\
\text { Packets) }\end{array}$ & $\%$ \\
\hline $2010-11$ & 10.8 & & 8.3 & & 81.7 & & 100.8 & \\
\hline $2011-12$ & 11.4 & 5.6 & 8.3 & 0.0 & 98.2 & 20.2 & 117.9 & 17.0 \\
\hline $2012-13$ & 12.5 & 9.6 & 7.8 & $(-) 6.0$ & 127.3 & 29.6 & 147.6 & 25.2 \\
\hline $2013-14$ & 14.4 & 15.2 & 10.5 & 34.6 & 148.2 & 16.4 & 173.1 & 17.3 \\
\hline $2014-15$ & 8.7 & $(-) 39.6$ & 10.3 & $(-) 1.9$ & 158.8 & 7.2 & 177.8 & 2.7 \\
\hline Average & 11.6 & $(-) 2.3$ & 9.0 & 6.7 & 122.8 & 18.3 & 143.4 & 15.5 \\
\hline
\end{tabular}

Source: Annual Reports of KCMMF 
The average growth rate of TRCMPU, ERCMPU MRCMPU was (-) 2.3 percent, 6.7 percent and 18.3 percent respectively. The average market share of TRCMPU, ERCMPU MRCMPU was 11.6 lakh packets per year, 9 lakh packets per year, and 122.8 lakh packets per year, respectively (Table 8 ). As per Figure 5, MRCMPU was far above from cell one as it had very high market growth and market share in respect of sambaram sales. Hence MRCMPU had extra ordinary position as regards sambaram sales. TRCMPU was far below from cell IV as it had negative growth rate. . Hence TRCMPU had very low position. ERCMPU had low position in respect of sambaram sales.

Figure 5: Two by Two Matrix of Union wise Sambaram Sales

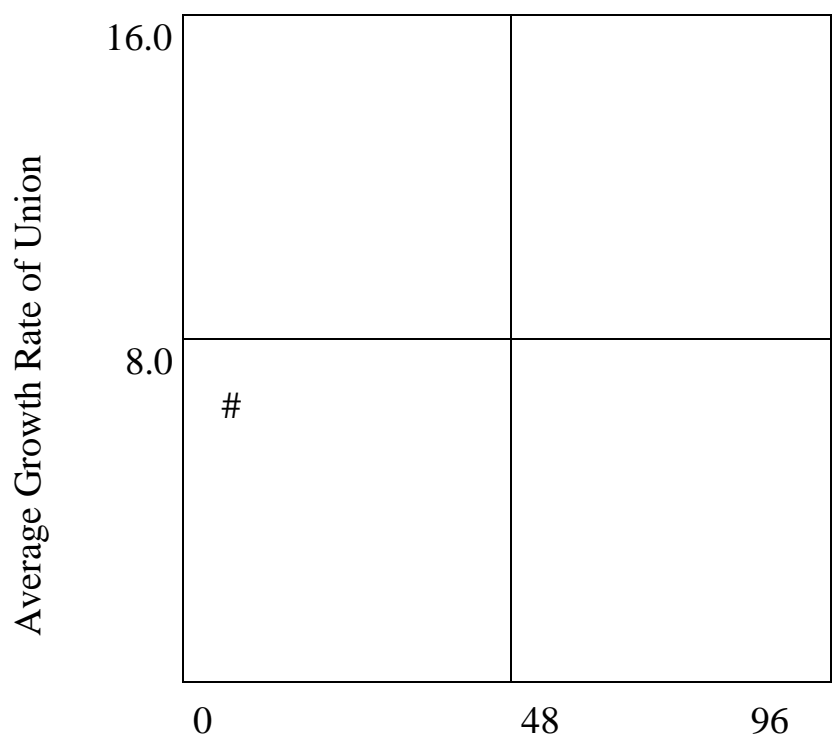

Average Market Share of Union

\section{e. Union wise Selling of Ice-cream}

The annual growth rate of selling of ice-cream by all unions showed mixed trend. The average annual growth rate of selling of ice-cream by TRCMPU, ERCMPU and MRCMPU was 12.0 percent, 16.5 percent, and 35.9 percent respectively. The overall average annual growth rate of icecream sales of three unions was 20.7 percent (Table 9).

Table 9: Annual Growth Rate of Ice - cream Sales Per Year

\begin{tabular}{|c|c|c|c|c|c|c|c|c|}
\hline & \multicolumn{2}{|c|}{ TRCMPU } & \multicolumn{2}{c|}{ ERCMPU } & \multicolumn{2}{c|}{ MRCMPU } & \multicolumn{2}{c|}{ Total } \\
\hline & $\begin{array}{c}\text { (in Lakh } \\
\text { Litres) }\end{array}$ & $\%$ & $\begin{array}{c}\text { in Lakh } \\
\text { Litres) }\end{array}$ & $\%$ & $\begin{array}{c}\text { in Lakh } \\
\text { Litres) }\end{array}$ & $\%$ & $\begin{array}{c}\text { in Lakh } \\
\text { Litres) }\end{array}$ & $\%$ \\
\hline $2010-11$ & 1.8 & - & 4.3 & - & 3.0 & - & 9.1 & - \\
\hline $2011-12$ & 2.0 & 11.1 & 5.2 & 20.9 & 4.6 & 53.3 & 11.8 & 9.1 \\
\hline $2012-13$ & 2.3 & 15.0 & 6.1 & 17.3 & 6.7 & 45.7 & 15.1 & 11.8 \\
\hline
\end{tabular}




\begin{tabular}{|c|c|c|c|c|c|c|c|c|}
\hline $2013-14$ & 2.8 & 21.7 & 7.3 & 19.7 & 7.8 & 16.4 & 17.9 & 15.1 \\
\hline $2014-15$ & 2.8 & 0.0 & 7.9 & 8.2 & 10.0 & 28.2 & 20.7 & 17.9 \\
\hline Average & 2.3 & 12.0 & 6.2 & 16.5 & 6.4 & 35.9 & 14.9 & 20.7 \\
\hline
\end{tabular}

Source: Annual Reports of KCMMF

The average growth rate of TRCMPU, ERCMPU MRCMPU was 12.0 percent, 16.5 percent and 35.9 percent respectively. The average market share of TRCMPU, ERCMPU MRCMPU was 2.3 lakh litres per year, 6.2 lakh litres per year, and 6.4 lakh litres per year respectively (Table 9). As per Figure 6 MRCMPU had very high position, ERCMPU had high position and TRCMPU had low position and in respect of ice-cream sales.

\section{Figure 6: Two by Two Matrix of Union wise Ice-cream Sales}

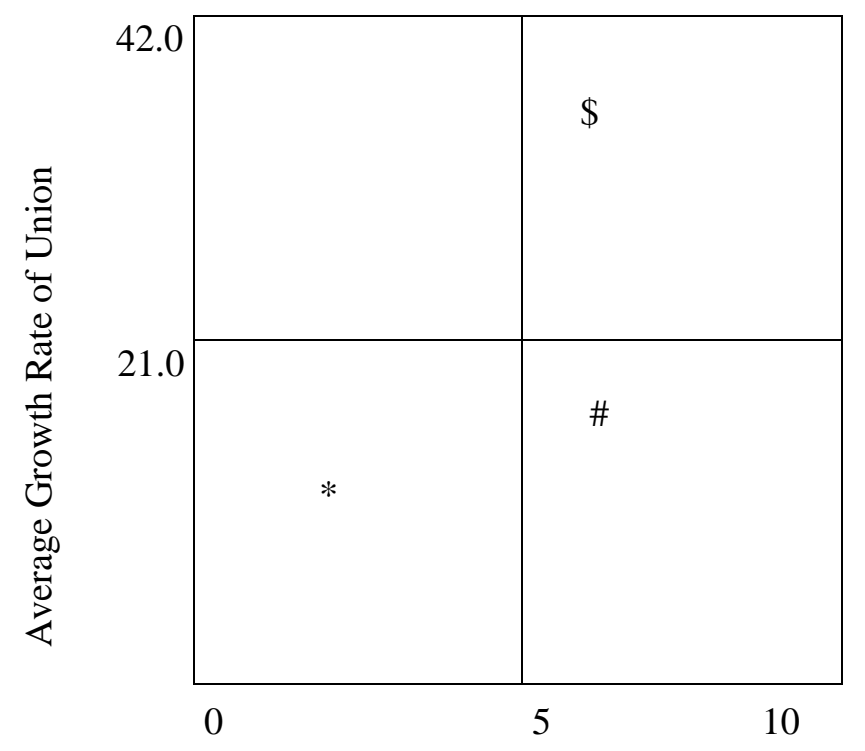

Average Market Share of Union

\section{Overall score of Unions}

From the results of two by two matrix, the overall score of three unions can be ascertained. The union which lay in cell I was given four points, cell II was given three points, cell III was given two points and cell IV was given one point. The union which lay far above from Cell I was given additional one point and the union which lay far below from Cell IV got negative one. As per table MRCMPU had got 21 points, ERCMPU had got 13 points and TRCMPU had got 11 points. MRCMPU had high competitive position than other two unions.

Table 10: Overall score of Unions

\begin{tabular}{|l|c|c|c|c|c|c|c|c|c|c|c|c|}
\hline & \multicolumn{4}{|c|}{ TRCMPU } & \multicolumn{4}{c|}{ ERCMPU } & \multicolumn{5}{c|}{ MRCMPU } \\
\hline & VH & H & M & L & VH & H & M & L & VH & H & M & L \\
\hline Milk & & 3 & & & & & 2 & & 4 & & & \\
\hline Ghee & & & 2 & & & & 2 & & & 3 & & \\
\hline Butter Milk & & 3 & & & & 3 & & & & & 2 & \\
\hline Curd & & & 2 & & & & 2 & & & 3 & & \\
\hline
\end{tabular}




\begin{tabular}{|l|l|l|l|c|c|c|c|c|c|c|c|c|}
\hline Sambaram & & & & $1-1$ & & & & 1 & $4+1$ & & & \\
\hline Ice-cream & & & & 1 & & 3 & & & 4 & & & \\
\hline Total & & 6 & 4 & 1 & & 6 & 6 & 1 & 13 & 6 & 2 & \\
\hline
\end{tabular}

Overall score - T RCMPU 11, ERCMPU 13, MRCMPU 21

\section{Conclusion}

This study makes an attempt to ascertain the current level of competitiveness of various Unions of KCMMF. As Milma is processing and selling milk and milk products in large scale, a small change in the procurement and selling price ultimately results high change in the earnings of Milma at the end. Increase in the selling price of milk and milk products is not the ultimate solution to solve the present problems of Milma but it has to assess the competitiveness of unions. Survival and growth of Milma is not the responsibility of Milma alone but the responsibility of farmers, consumers, employees, public, govt. and the society as a whole.

\section{Reference}

1. Annual Report of Milma 2014-15.

Appendix I: Average Market Share of Milk and Milk Products of Unions

\begin{tabular}{|l|l|c|c|c|}
\hline & TRCMPU & ERCMPU & MRCMPU & Mid Value \\
\hline Milk (in Lakh Litres) & 4.6 & 3.0 & 4.2 & 4.0 \\
\hline Ghee ( in '000MT) & 1.1 & 0.8 & 2.0 & 1.3 \\
\hline Butter Milk ( in'00 MT) & 1.2 & 0.9 & 0.3 & 0.8 \\
\hline Curd ( in '000MT) & 5.6 & 4.9 & 17.7 & 9.3 \\
\hline Sambaram ( In Lakh Packets) & 11.6 & 9.0 & 122.8 & 48 \\
\hline Ice-cream ( In Lakh Litres) & 2.3 & 6.2 & 6.4 & 5.0 \\
\hline
\end{tabular}

Source: Compiled from the data

Appendix II: Average Growth rate of Milk and Milk Products of Unions (in Percent)

\begin{tabular}{|l|l|c|c|c|}
\hline & TRCMPU & ERCMPU & MRCMPU & Mid Value \\
\hline Milk & 2.1 & 3.1 & 3.5 & 3.0 \\
\hline Ghee & 14.7 & 12.7 & 6.5 & 11.0 \\
\hline
\end{tabular}


IRA-International Journal of Management \& Social Sciences

\begin{tabular}{|l|l|c|c|c|}
\hline Butter Milk & 26.6 & 24.2 & 34.7 & 29.0 \\
\hline Curd & 8.9 & 5.7 & 5.2 & 7.0 \\
\hline Sambaram & $(-) 2.3$ & 6.7 & 18.3 & 8.0 \\
\hline Ice-cream & 12.0 & 16.5 & 35.9 & 21.0 \\
\hline
\end{tabular}

Source: Compiled from the data 